\title{
Studi Evaluasi Pengerukan Sedimen pada Central Sediment Sump di Lokasi Penambangan Emas PT. Bumi Suksesindo Kabupaten Banyuwangi
}

\author{
Yana Cunanda $^{1 *}$, Runi Asmaranto ${ }^{1}$, Prima Hadi Wicaksono ${ }^{1}$ \\ ${ }^{1}$ Jurusan Teknik Pengairan, Fakultas Teknik, Universitas Brawijaya, \\ Jalan MT. Haryono No. 167, Malang, 65145, INDONESIA \\ *Korespondensi Email : ycunanda@gmail.com
}

\begin{abstract}
Central Sediment Sump (CSS) is the biggest sedimentation pond in the gold mining of PT. Bumi Suksesindo. It accommodates total of sediment from some areas: Central Waste Dump (CWD), Pit E, and Pit B West. Starting in 2018, there is an increasing in ore production to 8.1 million tons/year and it caused the amount of sediment accumulated in CSS is getting bigger. Furthermore, the sum of sediment load trapped in CSS is also induced by catchment erosion. This present study assessed the amount of dredged sediment volume in the year of 2018 and total accumulated sediment in CSS. The amount of dredged sediment will be depending on the bucket size, unit cycle time and working/operating hours of excavators. The result of this study informed that the total volume of sediment accumulated in CSS was $2,004,551.730 \mathrm{~m}^{3}$. The total sediment volume dredged in 2018 was $11,755.310$ $\mathrm{m}^{3}$, it was much lower than collected sediment volume in CSS.
\end{abstract}

Keywords: Dredging, Sediment, Volume

\begin{abstract}
Abstrak: Central Sediment Sump merupakan kolam pengendapan sedimen terbesar di Penambangan Emas PT. Bumi Suksesindo. Central Sediment Sump menampung sedimen dari kawasan Central Waste Dump (CWD), Pit E, dan Pit B West. Adanya peningkatan produksi bijih mulai tahun 2018 menjadikan laju penambangan hingga 8,1 juta ton/tahun. Peningkatan ini mengakibatkan meningkatnya laju sedimen yang ditampung Central Sediment Sump. Evaluasi yang dilakukan pada studi ini berdasarkan pada jumlah volume sedimen terkeruk selama tahun 2018 terhadap volume sedimen yang tertangkap di Central Sediment Sump. Volume sedimen yang berasal dari hasil erosi di daerah tangkapan air Central Sediment Sump akan tertangkap di Central Sediment Sump. Volume sedimen terkeruk tergantung pada ukuran bucket excavator, waktu siklus excavator, dan waktu kerja excavator. Waktu kerja excavator menggambarkan waktu yang diperlukan untuk memindahkan volume sedimen yang sudah ditentukan. Hasil evaluasi pengerukan sedimen akan menggambarkan cukup atau tidaknya pengerukan sedimen tahun 2018 untuk mengeruk sedimen yang tertangkap di Central Sediment Sump. Berdasarkan hasil studi ini diperoleh volume sedimen yang tertangkap di Central Sediment Sump sebesar 2.004.551,730 $\mathrm{m}^{3}$. Volume sedimen terkeruk selama tahun 2018 sebesar $11.755,310 \mathrm{~m}^{3}$. Sehingga pengerukan sedimen tahun 2018 tidak mencukupi untuk mengeruk seluruh volume sedimen yang tertangkap di Central Sediment Sump.
\end{abstract}

Kata kunci: Pengerukan, Sedimen, Volume 


\section{Pendahuluan}

Penambangan sistem terbuka konvensional banyak mengubah bentang lahan dan keseimbangan ekosistem permukaan tanah, menurunkan produktivitas tanah dan mutu lingkungan [1]. Pada Proyek Tujuh Bukit, sedimentasi merupakan dampak yang terjadi akibat dari penerapan sistem pertambangan terbuka. Untuk mengendalikan sedimentasi yang terjadi di area-area tersebut, salah satu usaha yang dilakukan adalah dengan membangun kolam pengendapan. Central Sediment Sump (CSS) merupakan kolam pengendapan terbesar yang ada di Penambangan Tujuh Bukit. Kolam ini memiliki fungsi menampung dan mengendapkan sedimen yang berasal dari Central Waste Dump (CWD), Pit E, dan Pit B West seluas 62,41 ha dan memiliki volume tampungan sebesar $12.235 \mathrm{~m}^{3}$. Terkait fungsinya untuk menampung dan mengendapkan sedimen selama masa penambangan, pemeliharaan dilakukan pada tampungan kolam adalah melakukan pengerukan sedimen menggunakan excavator. Sedimen yang sudah dikeruk selanjutnya dapat langsung diangkut ke area penimbunan untuk dikeringkan.

Tujuan dari studi ini adalah untuk menentukan laju erosi dan sedimentasi di Daerah Tangkapan Air (DTA) Central Sediment Sump setiap bulannya pada tahun 2018, menentukan volume total sedimen yang tertangkap di Central Sediment Sump pada tahun 2018, mengevaluasi pengerukan sedimen yang sudah dilakukan di tahun 2018, dan memberikan rekomendasi penggunaan alat berat yang sesuai untuk pengerukan sediment yang sesuai dengan kondisi tahun 2018.

\section{Metode Penelitian}

\subsection{Lokasi Studi}

Lokasi studi adalah kolam pengendapan Central Sediment Sump (CSS) berada di wilayah Pertambangan Emas Tujuh Bukit (Tumpang Pitu). Pertambangan Tujuh Bukit berada di Pegunungan Tumpang Pitu, Desa Sumberagung Kecamatan Pesanggaran, Kabupaten Banyuwangi, Jawa Timur. Kondisi awal dari Tumpang Pitu adalah kawasan hutan produksi yang memiliki topografi bergelombang dan curam dikarenakan berada di daerah perbukitan. Kondisi saat ini dari lokasi studi memiliki topografi yang bervariatif, dengan kemiringan antara 0\% hingga lebih dari 40\% menyesuaikan dengan kebutuhan wilayah Pertambangan Tujuh Bukit serta memiliki tata guna lahan yang bervariatif dengan didominasi oleh area tambang terbuka.

\subsection{Metode}

\subsubsection{Uji Konsistensi Data Curah Hujan}

Uji konsistensi data curah hujan menggunakan Metode Rescaled Adjusted Partial Sums (RAPS) [2]. Adapun persamaan-persamaan yang digunakan adalah berikut:

$$
\begin{aligned}
& S_{k}{ }^{*}=\sum_{i=1}^{k}\left(Y_{i}-\bar{Y}\right) \\
& S_{k}{ }^{* *}=\frac{S_{k}{ }^{*}}{D_{y}} \\
& D_{y}{ }^{2}=\sum_{i=1}^{N} \frac{\left(Y_{i}-\bar{Y}\right)^{2}}{N} \\
& \mathrm{Q}_{\text {Hitung }}=\mid S_{k}{ }^{* *} \text { Maks }_{\text {Mat }} \mid \\
& \mathrm{R}_{\text {Hitung }}=S_{k}{ }^{* *}{ }_{\text {Maks }}-S_{k}{ }^{* *} \text { Min }
\end{aligned}
$$


dengan:

$\mathrm{S}_{\mathrm{k}}{ }^{*} \quad=$ Nilai kumulatif penyimpangan terhadap nilai rata-rata

$\mathrm{Y}_{\mathrm{i}} \quad=$ Nilai data $\mathrm{Y}$ ke- $\mathrm{i}$

$\overline{\mathrm{Y}} \quad=$ Nilai Y rata-rata

$\mathrm{S}_{\mathrm{k}}^{* *}=$ Rescaled Adjusted Partial Sums (RAPS)

Dy $=$ Standar deviasi seri data $\mathrm{Y}$

\subsubsection{Aliran Permukaan Metode SCS-CN}

Persamaan untuk menentukan aliran permukaan adalah dengan metode SCS-CN [3]:

Untuk P > Ia

$V o=\frac{(P-I a)^{2}}{(P-I a)+S}$

Untuk P $<$ Ia

$V_{0}=0$

$I a=0,2 S$

$S=\frac{25400}{C N}-254$

Pers. 9

dengan:

Vo = Kedalaman aliran permukaan $(\mathrm{mm})$

$\mathrm{P} \quad=$ Curah hujan $(\mathrm{mm})$

Ia $\quad=$ Abstraksi awal $(\mathrm{mm})$

$\mathrm{S} \quad=$ Retensi potensial maksimum $(\mathrm{mm})$

$\mathrm{CN}=$ Curve Number

Nilai CN ditentukan berdasarkan tata guna lahan atau tutupan lahan, penanganan terhadap lahan, kondisi hidrologi pada lahan, dan kelompok tanah. Keempat faktor tersebut akan membentuk Hydrological Soil-Cover Complex [3]. Nilai CN dapat berbentuk komposit, yaitu merupakan nilai CN untuk sebuah daerah tangkapan dengan persamaan sebagai berikut:

$C N_{\text {Komposit }}=\frac{\sum_{i=1}^{n} C N_{i} A_{i}}{\sum_{i=1}^{n} A_{i}}$

Pers. 10

dengan:

$\mathrm{CN}_{\mathrm{i}}=$ Nilai $\mathrm{CN}$ dengan jenis tutupan tanah $\mathrm{i}$

$\mathrm{A}_{\mathrm{i}} \quad=$ Luas lahan dengan jenis tutupan tanah $\mathrm{i}$

$\mathrm{n} \quad=$ Jumlah tutupan lahan 


\subsubsection{Analisis Debit Puncak}

US-SCS mengembangkan sebuah persamaan menggunakan koefisien yang berhubungan dengan elemen hidrograf dan karakteristik daerah tangkapan. Karakteristik daerah tangkapan yang digunakan adalah luas area, panjang maksimum aliran, dan slope [4]. Persamaan tersebut adalah sebagai berikut:

$Q p=0,2008 \cdot \frac{A \cdot V o}{T p}$

$T p=0,7 . T c$

Pers. 12

$T C=0,0195 \cdot L^{0,77} \cdot I^{-0,385}$

Pers. 13

dengan:

Qp $\quad=$ Debit puncak $\left(\mathrm{m}^{3} /\right.$ detik $)$

A $\quad=$ Luas lahan $\left(\mathrm{km}^{2}\right)$

Vo $=$ Aliran permukaan $(\mathrm{mm})$

$\mathrm{Tp} \quad=$ Time peak $(\mathrm{jam})$

Tc $\quad=$ Waktu konsentrasi (jam)

$\mathrm{L} \quad=$ Panjang maksimum aliran $(\mathrm{m})$

$\mathrm{I} \quad=$ Slope

\subsubsection{Pendugaan Erosi Metode MUSLE}

Metode ini merupakan modifikasi dari metode USLE. Metode MUSLE dikembangkan oleh United States Department of Agriculture (USDA) bekerja sama dengan Universitas Purdue pada tahun 1954. MUSLE tidak menggunakan faktor energi hujan sebagai penyebab terjadinya erosi melainkan menggunakan faktor limpasan permukaan, sehingga MUSLE tidak memberikan faktor sediment delivery ratio (SDR), karena nilainya bervariasi dari satu tempat ke tempat lainnya [5]. Metode MUSLE dapat memperhitungkan erosi maupun pergerakan sedimen pada DAS dengan baik berdasarkan kejadian hujan tunggal [6], dengan persamaan sebagai berikut:

$S Y=R_{w} \cdot K \cdot L S \cdot C P$

Pers. 14

$Q s=S Y . A$

dengan:

SY = Jumlah tanah tererosi (ton/ha/tahun)

$\mathrm{R}_{\mathrm{w}} \quad=$ Faktor limpasan permukaan

$\mathrm{K} \quad=$ Faktor erodibilitas tanah

LS $\quad=$ Faktor kemiringan lereng

$\mathrm{CP} \quad=$ Faktor pengelolaan tanaman dan konservasi tanah

Qs = Laju sedimentasi (ton/tahun)

A = Luas area (ha) 


\subsubsection{Indeks Erosivitas Limpasan Permukaan (Rw)}

Untuk menduga hasil endapan dari setiap kejadian limpasan permukaan dengan cara mengganti indeks erosivitas $(R)$ dengan indeks limpasan permukaan $\left(R_{w}\right)[6]$ sebagai berikut:

$R_{w}=11,8 \cdot\left(V_{o} \cdot Q_{b}\right)^{0,56}$

Pers. 16

dengan:

$\mathrm{Rw}=$ Indeks erosivitas limpasan permukaan

Vo $\quad=$ Volume limpasan permukaan $\left(\mathrm{m}^{3}\right)$

Qp $\quad=$ Debit puncak $\left(\mathrm{m}^{3} /\right.$ detik $)$

\subsubsection{Indeks Erodibilitas Tanah (K)}

Faktor erodibilitas tanah $(\mathrm{K})$ menunjukkan resistensi pertikel tanah terhadap pengelupasan dan transportasi pertikel-partikel tanah tersebut oleh adanya energi kinetik air hujan [6]. Perhitungan erosi lahan (USLE/MUSLE) perlu dibedakan antara faktor erodibilitas tanah pada musim kemarau dan musim penghujan karena adanya pengaruh kadar air dalam tanah [7]. Nilai erodibilitas tanah dapat ditentukan dengan menggunakan persamaan sebagai berikut:

$100 K=1,292\left[2,1 M^{1,14} \cdot\left(10^{-4}\right) \cdot(12-O M)+3,25(b-2)+2,5(c-3)\right] \quad$ Pers. 17

$M=\left(m_{v f s}+m_{\text {silt }}\right) \cdot\left(100-m_{c}\right)$

Pers. 18

$O M=1,72(\operatorname{org} C)$

Pers. 19

dengan:

$\mathrm{K}=$ Nilai erodibilitas tanah

$\mathrm{M}=$ Persentase fraksi pasir sangat halus (diameter 0,1-0,05 $\mathrm{mm}$ ) dan fraksi lebih halus (diameter $0,05-0,02 \mathrm{~mm}) \mathrm{x}(100-$ persentase lempung)

$\mathrm{OM}=$ Persentase bahan organik

$\mathrm{b} \quad=$ Kode struktur tanah

c $\quad=$ Kode permeabilitas tanah

$\mathrm{m}_{\mathrm{vfs}} \quad=$ Persentase pasir sangat halus

$\mathrm{m}_{\text {silt }} \quad=$ Persentase debu

$\mathrm{m}_{\mathrm{c}} \quad=$ Persentase liat

$\operatorname{org} \mathrm{C}=$ Persentase karbon organik

\subsubsection{Faktor Panjang dan Kemiringan Lereng (LS)}

Faktor indeks topografi L dan S masing-masing mewakili pengaruh panjang dan kemiringan lereng terhadap bersarnya erosi [6]. Panjang lereng mengacu pada lokasi berlangsungnya erosi dan kemungkinan terjadinya deposisi sedimen. Kemiringan lereng digunakan sebagai faktor yang seragam.Faktor LS dapat ditentukan berdasarkan kemiringan lerengnya. 
Tabel 1. Kode struktur tanah (b) [8]

\begin{tabular}{lc}
\hline Kelas Struktur Tanah & Kode $(\mathrm{b})$ \\
\hline Granuler sangat halus $(<1 \mathrm{~mm})$ & 1 \\
Granuler halus $(1-2 \mathrm{~mm})$ & 2 \\
Granuler sedang sampai kasar $(2-10 \mathrm{~mm})$ & 3 \\
Berbentuk blok, pelat, masif & 4 \\
\hline
\end{tabular}

Tabel 2. Kode permeabilitas tanah (c) [8]

\begin{tabular}{lcc}
\hline Kelas Permeabilitas & Kecepatan $(\mathrm{cm} / \mathrm{jam})$ & Kode $(\mathrm{c})$ \\
\hline Sangat lambat & $<0,5$ & 6 \\
Lambat & $0,5-2,0$ & 5 \\
Lambat sampai sedang & $2,0-6,3$ & 4 \\
Sedang & $6,3-12,7$ & 3 \\
Sedang sampai cepat & $12,7-25,4$ & 2 \\
Cepat & $>25,4$ & 1 \\
\hline
\end{tabular}

Tabel 3. Faktor LS berdasarkan kelas kemiringan lereng

\begin{tabular}{ccc}
\hline Kelas Lereng & Kemiringan Lereng $(\%)$ & Faktor LS \\
\hline \hline I & $0-8$ & 0,40 \\
II & $8-15$ & 1,40 \\
III & $15-25$ & 3,10 \\
IV & $25-40$ & 6,80 \\
V & $>40$ & 9,50 \\
\hline
\end{tabular}

\subsubsection{Faktor Pengelolaan Tanaman dan Konservasi Tanah (CP)}

Vegetasi dan tindakan konservasi tanah juga memengaruhi tingkat erosi yang terjadi. Lahan yang tidak ditanami dan tanpa tindakan konservasi akan memiliki nilai erosi yang lebih besar daripada lahan dengan kondisi vegetasi yang baik dan dikonservasi. Untuk tanah kosong atau tanah yang sedang dalam pembangunan proyek memiliki nilai $\mathrm{C}=1$ dan $\mathrm{P}=1$. Penilaian faktor $\mathrm{P}$ di lapangan akan lebih mudah bila digabungkan dengan faktor $\mathrm{C}$ karena kedua faktor ini memiliki kaitan yang erat.

Tabel 4. Nilai faktor CP [6]

\begin{tabular}{lc}
\hline Konservasi dan Pengelolaan Tanaman & Nilai CP \\
\hline \hline Hutan tak terganggu & 0,01 \\
Semak sebagian berumput & 0,10 \\
Perumputan tanah sempurna & 0,01 \\
Tanaman pertanian biji-bijian & 0,36 \\
\hline
\end{tabular}

\subsubsection{Debit Sedimen}

Dengan mengasumsikan bahwa konsentrasi sedimen merata pada seluruh penampang melintang sungai atau saluran, maka debit sedimen dapat dihitung dengan rumus sebagai berikut:

$Q s=0,0864 \cdot Q w \cdot C s$

Pers. 20

dengan:

Qs $\quad=$ Debit sedimen (ton/hari)

$\mathrm{Qw} \quad=$ Debit aliran sungai $\left(\mathrm{m}^{3} /\right.$ detik $)$ 
Cs $\quad=$ Konsentrasi sedimen

Untuk data debit aliran sungai atau saluran dan muatan sedimen sedimen bulanan atau tahunan dapat menggunakan kurva hubungan antara debit aliran sungai/saluran dengan debit sedimen yang disebut dengan sediment discharge rating curve. Dengan menggunakan persamaan regresi sederhana kurva berpangkat dapat dibuat hubungan antara debit aliran dengan besarnya aliran sedimen di lokasi pengamatan. Model regresi dianggap semakin baik jika nilai $\mathrm{r}^{2}$ mendekati 1 .

\subsubsection{Metode Brune}

Metode Brune digunakan untuk menentukan trap efficiency dari suatu tampungan untuk menahan sedimen [9]. Volume sedimen yang tertangkap di dalam tampungan dapat ditentukan dengan menggunakan persamaan sebagai berikut:

$Y=100 \cdot\left(1-\frac{1}{1+\alpha x}\right)^{n \prime}$

$V s$

$=Y \cdot Q S$

Pers. 22

dengan:

$\mathrm{Y} \quad=$ Efisiensi tampungan

$\mathrm{x}=$ Perbandingan kapasitas tampungan dengan inflow

$\alpha \quad=$ Konstanta

n' $\quad=$ Konstanta

Vs $=$ Volume sedimen tertahan $\left(\mathrm{m}^{3}\right)$

Qs $\quad=$ Debit sedimen $\left(\mathrm{m}^{3}\right)$

\subsubsection{Analisis Penggunaan Alat Berat}

\subsubsection{Produktivitas Excavator}

Produksi kerja excavator secara umum dapat ditentukan dengan rumus sebagai berikut [10]:

$P e=\frac{60}{C m e} \cdot q \cdot E_{e}$

$T_{e}$

$=\frac{V s}{P e}$

dengan:

$\mathrm{Pe} \quad=$ Produktivitas excavator $\left(\mathrm{m}^{3} / \mathrm{jam}\right)$

Cme = Waktu siklus excavator (menit)

$\mathrm{q} \quad=$ Kapasitas aktual bucket $\left(\mathrm{m}^{3}\right)$

Ee $\quad=$ Faktor efektivitas

$\mathrm{Te} \quad=$ Waktu kerja $(\mathrm{jam})$ 


\subsubsection{Produktivitas Dump Truck}

Produktivitas dump truck dapat ditentukan dengan persamaan sebagai berikut [11]:

$P_{d t}=\frac{60}{C m_{d t}} \cdot C \cdot E_{d t}$

$$
\begin{aligned}
& M \\
& =\frac{P e}{P d t}
\end{aligned}
$$

dengan:

$\mathrm{P}_{\mathrm{dt}} \quad=$ Produktivitas dump truck $\left(\mathrm{m}^{3} / \mathrm{jam}\right)$

$\mathrm{C} \quad=$ Kapasitas bak $\left(\mathrm{m}^{3}\right)$

$\mathrm{Cm}_{\mathrm{dt}} \quad=$ Waktu siklus dump truck (menit)

$\mathrm{q} \quad=$ Kapasitas aktual bucket $\left(\mathrm{m}^{3}\right)$

$\mathrm{E}_{\mathrm{dt}} \quad=$ Faktor efektivitas

$\mathrm{M} \quad=$ Jumlah dump truck

Waktu siklus dump truck ditentukan berdasarkan satu siklus pekerjaan (waktu muat, waktu angkut, waktu kembali, waktu buang, dan waktu tunggu).

\subsubsection{Keserasian Kerja Alat Berat}

Match factor digunakan untuk mengetahui jumlah alat angkut yang sesuai untuk melayani satu unit alat gali muat. Keserasian kerja alat angkut dan alat gali muat tercapai jika nilai $\mathrm{MF}=1$. Match factor dirumuskan sebagai berikut:

$$
M F=\frac{N_{d t} \cdot s \cdot C m_{e}}{N_{e} \cdot C m_{d t}}
$$

dengan:

$$
\begin{array}{ll}
\mathrm{MF} & =\text { Match factor } \\
\mathrm{N}_{\mathrm{dt}} & =\text { Jumlah dump truck } \\
\mathrm{S} & =\text { Jumlah pengisian dump truck } \\
\mathrm{Ne} & =\text { Jumlah excavator }
\end{array}
$$

\section{Hasil dan Pembahasan}

\subsection{Uji RAPS Data Curah Hujan}

Hasil Uji RAPS data curah hujan tahun 2017 dan 2018 di Pos Hujan Mine tersaji pada Tabel 5.

Tabel 5. Rekapitulasi hasil uji RAPS Pos Hujan Mine

\begin{tabular}{cccc}
\hline Tahun & Qkriti & Qhitung & Keterangan \\
\hline \hline 2017 & 1,05 & 0,698 & Diterima \\
2018 & 1,05 & 0,765 & Diterima \\
\hline
\end{tabular}


Berdasarkan hasil perhitungan uji RAPS curah hujan tahun 2017 diperoleh nilai $\mathrm{Q}_{\text {hitung }}<\mathrm{Q}_{\text {kritis }}$, serta tahun 2018 diperoleh nilai $\mathrm{Q}_{\text {hitung }}<\mathrm{Q}_{\text {kritis}}$, sehingga dapat disimpulkan bahwa data curah hujan bersifat konsisten.

\subsection{Analisis Aliran Permukaan}

Jenis tutupan lahan pada DTA Central Sediment Sump adalah: hutan, covercrop, tanaman turi, tanaman kacang-kacangan, rumput, dan lahan terbuka. Dengan menggunakan Metode SCS-CN diperoleh nilai aliran permukaan yang tersaji pada Tabel 6 .

Tabel 6. Rekapitulasi aliran permukaan

\begin{tabular}{ccccr}
\hline Tahun & Jenis Lahan & CN & \multicolumn{2}{c}{ Aliran Permukaan $\left(\mathrm{m}^{3}\right)$} \\
& & & Min & \multicolumn{1}{c}{ Maks } \\
\hline \multirow{2}{*}{2017} & Hutan & 70 & 0,000 & $27.896,525$ \\
& Covercrop & 80 & 0,000 & $9.000,112$ \\
& Tanaman Turi & 82 & 0,000 & $3.944,756$ \\
& Rumput & 74 & 0,000 & $19.058,226$ \\
& Lahan Terbuka & 89 & 0,737 & $220.538,898$ \\
& Hutan & 70 & 0,000 & $41.762,752$ \\
& Covercrop & 80 & 0,000 & $14.405,669$ \\
& Tanaman Turi & 82 & 0,000 & $5.717,511$ \\
& Tanaman Kacang-Kacangan & 82 & 0,000 & $1.485,217$ \\
& Lahan Terbuka & 89 & 0,000 & $314.700,237$ \\
& Rumput & 74 & $5.712,81$ & $28.199,074$ \\
\hline
\end{tabular}

Berdasarkan hasil analisis aliran permukaan diperoleh aliran permukaan yang bervariatif pada masing-masing jenis lahan.

\subsection{Analisis Debit Puncak}

Dengan panjang aliran utama drainase 1.888 meter dan slope rata- rata 0,097, maka nilai $\mathrm{Tc}=0,266$ jam dan nilai $\mathrm{Tp}=0,186$ jam diperoleh debit puncak yang tersaji pada Tabel 7 .

Tabel 7. Rekapitulasi debit puncak

\begin{tabular}{cccr}
\hline Tahun & Jenis Lahan & \multicolumn{2}{c}{ Debit Puncak $\left(\mathrm{m}^{3} / \mathrm{detik}\right)$} \\
& & Min & Maks \\
\hline 2017 & Hutan & 0,000 & 30,084 \\
& Covercrop & 0,000 & 9,706 \\
& Tanaman Turi & 0,000 & 4,254 \\
& Rumput & 0,000 & 20,553 \\
& Lahan Terbuka & 0,001 & 237,831 \\
& Hutan & 0,000 & 45,037 \\
& Covercrop & 0,000 & 14,136 \\
& Tanaman Turi & 0,000 & 6,166 \\
& Tanaman Kacang-Kacangan & 0,000 & 0,074 \\
& Lahan Terbuka & 0,000 & 339,376 \\
& Rumput & 6,161 & 30,410 \\
\hline
\end{tabular}

Berdasarkan hasil analisis debit puncak diperoleh debit puncak yang bervariatif pada masingmasing jenis lahan. 


\subsection{Indeks Limpasan Permukaan (Rw)}

Indeks limpasan permukaan ( $\mathrm{Rw}$ ) diperoleh berdasarkan jenis lahan (hutan, covercrop, tanaman turi, tanaman kacang-kacangan, rumput, dan lahan terbuka) dan menggunakan Persamaan 16, hasil yang diperoleh tersaji pada Tabel 8 .

Tabel 8. Rekapitulasi nilai Rw

\begin{tabular}{cccr}
\hline Tahun & Jenis Lahan & Min & Rw \\
& & 0,000 & Maks \\
\hline 2017 & Hutan & 0,000 & $6.505,140$ \\
& Covercrop & 0,000 & $2.740,208$ \\
& Tanaman Turi & 0,000 & $15.993,129$ \\
& Rumput & 0,183 & $248.281,573$ \\
& Lahan Terbuka & 0,000 & $38.505,687$ \\
& Hutan & 0,000 & $10.516,906$ \\
& Covercrop & 0,000 & $4.152,531$ \\
& Tanaman Turi & 0,000 & 193,985 \\
& Tanaman Kacang-Kacangan & 0,000 & $369.730,931$ \\
& Lahan Terbuka & $4.148,707$ & $24.802,993$ \\
\hline
\end{tabular}

Berdasarkan hasil analisis indeks limpasan permukaan diperoleh indeks limpasan permukaan yang bervariatif pada masing-masing jenis lahan.

\subsection{Indeks Erodibilitas Tanah (K)}

Indeks erodibilitas tanah $(\mathrm{K})$ diperoleh dari hasil sampel tanah yang diambil di area hutan, rehabilitasi dan lahan terbuka. Parameter - parameter pendukung diperoleh dengan melakukan pengujian di Laboratorium Fisika dan Laboratorium Kimia Fakultas Pertanian Universitas Brawijaya. Dengan menggunakan Persamaan 17 diperoleh nilai K yang tersaji pada Tabel 9.

Tabel 9. Nilai erodibilitas tanah

\begin{tabular}{ccc}
\hline No. & Nama Area & $\mathrm{K}$ \\
\hline 1. & Hutan & 0,321 \\
2. & Rehabilitasi & 0,404 \\
3. & Lahan Terbuka & 0,510 \\
\hline
\end{tabular}

Berdasarkan Tabel 9, diperoleh nilai erodibilitas tanah yang berbeda pada setiap nama area. Area Hutan memiliki nilai erodibilitas terendah dan Area Lahan Terbuka memiliki nilai erodibilitas tertinggi.

\subsection{Faktor LS dan Faktor CP}

Untuk pendugaan erosi, faktor panjang dan kemiringan lereng (LS) menggunakan nilai dari Tabel 3 dan faktor pengelolaan tanaman dan konservasi tanah (CP) menggunakan nilai dari Tabel 4.

\subsection{Pendugaan Erosi Metode MUSLE}

Hasil pendugaan erosi Metode MUSLE diperoleh dengan mengalikan faktor Rw, K, LS, dan CP. Dan untuk memperoleh hasil sedimentasi yang terjadi adalah dengan mengalikan hasil erosi yang terjadi dengan luas area masing-masing. Hasil pendugaan erosi dan sedimentasi tersaji pada Tabel 10. 
Tabel 10. Hasil pendugaan erosi dan sedimentasi

\begin{tabular}{ccc}
\hline \multirow{2}{*}{ Tahun } & $\begin{array}{c}\text { SY } \\
\text { (ton/ha/tahun) }\end{array}$ & $\begin{array}{c}\text { Qs } \\
\text { (ton/tahun) }\end{array}$ \\
\hline \hline 2017 & $227.565,413$ & $2.837 .682,773$ \\
2018 & $331.098,955$ & $4.437 .185,232$ \\
\hline
\end{tabular}

Pada tahun 2017, laju erosi yang terjadi sebesar 227.565,413 ton/ha/tahun dan laju sedimentasi yang terjadi sebesar 2.837.682,773 ton/tahun. Pada tahun 2018 laju erosi yang terjadi sebesar $331.098,955 \mathrm{ton} / \mathrm{ha} / \mathrm{tahun}$ dan laju sedimentasi yang terjadi sebesar 4.437.185,232 ton/tahun.

\subsection{Perbandingan Hasil Pendugaan Erosi Dengan Data Lapangan}

Data lapangan yang digunakan adalah data konsentrasi TSS harian yang tercatat pada tanggal 27 Desember 2017, 11 Januari 2018, dan 1 Februari 2018. Dari data konsentrasi sedimen yang tercatat, dibentuklah kurva hubungan antara debit air dan debit sedimen.

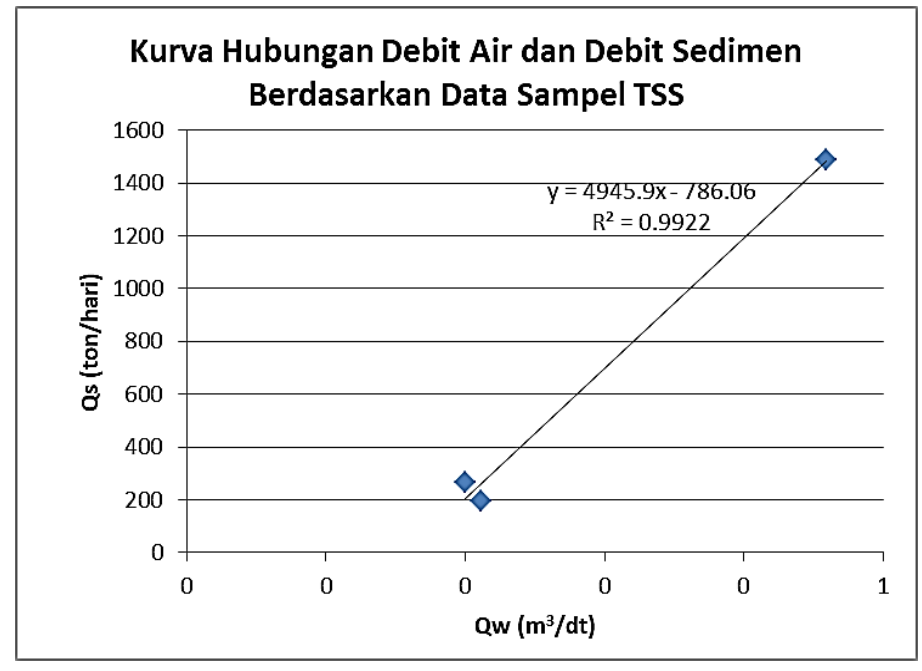

Gambar 1: Kurva debit air-sedimen

Pada Gambar 1, didapatkan nilai nilai $\mathrm{r}^{2}=0,9922$ dan persamaan $\mathrm{y}=4.945,9 \mathrm{x}-786,06$. Nilai $\mathrm{r}^{2}=$ 0,9922 menunjukkan bahwa model persamaan regresi di atas dapat menjelaskan variasi yang ada pada nilai Qs karena nilai $\mathrm{r}^{2}$ mendekati 1 . Selanjutnya dengan mengganti variabel $x$ dengan debit air $(\mathrm{Qw})$, maka persamaan di atas digunakan untuk menentukan debit sedimen setiap bulan atau setiap tahun di DTA Central Sediment Sump. Hasil perbandingan antara debit sedimen aktual dan debit sedimen hasil perhitungan tersaji pada Tabel 11.

Tabel 11. Perbandingan debit sedimen aktual dan debit sedimen hasil perhitungan

\begin{tabular}{cccc}
\hline Tahun & $\begin{array}{c}\text { Qs Aktual } \\
\text { (ton/tahun) }\end{array}$ & $\begin{array}{c}\text { Qs Perhitungan } \\
\text { (ton/tahun) }\end{array}$ & $\begin{array}{c}\text { KR } \\
(\%)\end{array}$ \\
\hline \hline 2017 & $2.620 .452,023$ & $2.837 .682,773$ & 8,29 \\
2018 & $5.505 .997,479$ & $4.437 .185,232$ & 19,41 \\
\hline
\end{tabular}

Berdasarkan tabel di atas terdapat penyimpangan antara debit sedimen aktual dan debit sedimen hasil perhitungan. Penyimpangan ini menunjukkan perbedaan antara debit sedimen aktual dengan debit sedimen hasil perhitungan. Pengukuran sampel TSS yang dilakukan tidak beragam, sehingga terdapat beberapa kondisi yang tidak terwakili di kurva hubungan debit air dan debit sedimen. 


\subsection{Volume Sedimen Tertangkap}

Volume total tampungan Central Sediment Sump sebesar $12.235 \mathrm{~m}^{3}$. Efektifitas Central Sediment Sump dalam menangkap sedimen diperoleh dengan menggunakan Persamaan 21 dan untuk volume sedimen yang tertangkap di Central Sediment Sump diperoleh dengan menggunakan Persamaan 22. Besarnya trap efficiency Central Sediment Sump setiap bulannya memengaruhi besarnya volume sedimen yang tertangkap di tampungan. Nilai $\alpha$ dan nilai n' yang digunakan pada studi ini menggunakan nilai rata-rata, yaitu nilai $\alpha=100$ dan nilai n' $=1,5$. Debit sedimen yang masuk dan volume sedimen yang tertangkap tersaji pada Tabel 12.

Tabel 12. Rekapitulasi volume sedimen tertangkap

\begin{tabular}{ccc}
\hline Tahun & $\begin{array}{c}\text { Qs } \\
\text { (ton) }\end{array}$ & $\begin{array}{c}\text { Vs } \\
\left(\mathrm{m}^{3}\right)\end{array}$ \\
\hline \hline 2017 & $2.837 .682,773$ & $837.777,734$ \\
2018 & $4.437 .185,232$ & $1.166 .773,996$ \\
\hline
\end{tabular}

Pada tahun 2017 didapatkan volume sedimen yang terendap sebesar 837.777,734 $\mathrm{m}^{3}$. Dan pada tahun 2018 sebesar 1.166.773,996 $\mathrm{m}^{3}$. Sehingga total volume sedimen yang terendap selama tahun 2017 hingga tahun 2018 sebesar 2.004.551,730 $\mathrm{m}^{3}$. Dengan volume tampungan Central Sediment Sump sebesar $12.235 \mathrm{~m}^{3}$, maka diperlukan pengerukan sedimen untuk memelihara Central Sediment Sump tetap dapat mengendapkan sedimen dari daerah tangkapannya dengan baik.

\subsection{Evaluasi Pengerukan Sedimen Eksisting Tahun 2018}

Pengerukan sedimen di Central Sediment Sump tahun 2018 dilakukan dengan menggunakan excavator sebagai alat pengeruk sedimen dan articulated dump truck sebagai alat pengangkut sedimen ke tempat pembuangan.

Pengerukan sedimen tahun 2018 menggunakan excavator 20 ton dengan total waktu kerja 15 jam serta produktivitas alat sebesar $46,154 \mathrm{~m} / \mathrm{jam}$ dan excavator long arm 20 ton dengan total waktu kerja 481 jam serta produktivitas alat sebesar $23 \mathrm{~m}^{3} / \mathrm{jam}$. Sehingga total volume sedimen yang berhasil dikeruk pada tahun 2018 sebesar $11.755,310 \mathrm{~m}^{3}$. Dengan kerja excavator yang sudah dilakukan masih terdapat volume sedimen tersisa di Central Sediment Sump sebesar 1.992.796,420 $\mathrm{m}^{3}$. Maka pengerukan sedimen yang sudah dilakukan di tahun 2018 belum dapat mengeruk seluruh sedimen yang terendapkan di Central Sediment Sump.

Articulated dump truck yang digunakan pada tahun 2018 berjumlah 1-3 buah dengan total waktu kerja sebesar 243,66 jam yang digunakan tidak selalu bersamaan dengan penggunaan excavator untuk mengeruk sedimen. Hal ini dikarenakan terdapat drying pad untuk mengeringkan sedimen sementara sedimen yang terlalu cair.

\subsection{Analisis Alternatif Penggunaan Alat Berat}

Analisis alternatif pengerukan sedimen dilakukan untuk menentukan alternatif penggunaan alat berat yang dibutuhkan untuk mengeruk sedimen di Central Sediment Sump.Alat berat yang digunakan pada analisis ini adalah excavator dan articulated dump truck.

Selanjutnya dari analisis ini akan diperoleh waktu kerja excavator yang diperlukan untuk mengeruk sedimen yang terendapkan di Central Sediment Sump dan waktu kerja serta jumlah articulated dump truck yang diperlukan untuk mengangkut sedimen yang sudah dikeruk menuju ke tempat pembuangan. Alternatif yang digunakan pada analisis ini adalah sebagai berikut:

a. Pengerukan sedimen dengan 1 excavator dengan kapasitas bucket $1 \mathrm{~m}^{3}$ dan pengangkutan sedimen menggunakan articulated dump truck dengan kapasitas bak $25 \mathrm{~m}^{3}$ untuk pembuangan ke Central Waste Dump. 
b. Digunakan tambahan 1 buah excavator dengan kapasitas bucket $1 \mathrm{~m}^{3}$ jika waktu kerja excavator sebelumnya melebihi waktu kerja maksimum dalam 1 bulan dan menggunakan tambahan tambahan articulated dump truck dengan kapasitas bak 20,6 $\mathrm{m}^{3}$ dan pembuangan sedimen ke Central Waste Dump.

c. Kerja excavator dibagi ke dalam dua shift kerja, yaitu day shift selama 10 jam dan night shift selama 9 jam.

d. Kerja articulated dump truck juga dibagi ke dalam dua shift kerja, yaitu day shift dan night shift.

Produktivitas excavator yang digunakan adalah sebagai berikut.

\section{Spesifikasi Excavator}

\begin{tabular}{|c|c|c|c|}
\hline \multicolumn{3}{|l|}{ Tipe } & 20 ton \\
\hline \multicolumn{3}{|c|}{ Volume bucket } & $1 \mathrm{~m}^{3}$ \\
\hline \multicolumn{3}{|c|}{ Faktor pengisian bucket } & 1 \\
\hline \multicolumn{3}{|c|}{ Waktu siklus } & 0,4 menit \\
\hline \multicolumn{3}{|c|}{ Efisiensi alat } & 0,75 \\
\hline \multicolumn{3}{|c|}{ Waktu siklus } & 0,4 menit \\
\hline $\mathrm{q}_{0}$ & $=$ & $1,00 \mathrm{~m}^{3}$ & \\
\hline $\mathrm{k}$ & $=$ & 1 & \\
\hline q & $=$ & $\mathrm{q}_{0} \cdot \mathrm{k}$ & \\
\hline q & $=$ & $1,00.1$ & \\
\hline q & $=$ & $1,00 \mathrm{~m}^{3}$ & \\
\hline Cme & $=$ & 0,4 menit & \\
\hline $\mathrm{Ee}$ & $=$ & 0,75 & \\
\hline $\mathrm{Pe}$ & $=$ & $\frac{60}{\mathrm{Cme}} \cdot \mathrm{q} \cdot \mathrm{F}$ & \\
\hline $\mathrm{Pe}$ & $=$ & $\frac{60}{0,4} \cdot 1,00$ &, 75 \\
\hline $\mathrm{Pe}$ & $=$ & $112,500 \mathrm{n}$ & jam \\
\hline
\end{tabular}

Produktivitas dump truck yang digunakan adalah sebagai berikut:

\section{$\underline{\text { Spesifikasi dump truck }}$}

Tipe $\quad$ : Articulated Dump Truck

Efisiensi alat : 0,69

Kapasitas bak : $20,6 \mathrm{~m}^{3}$

Waktu siklus dump truck

$\begin{array}{ll}\text { Waktu muat }(\mathrm{Wm}) & =8,4 \text { menit } \\ \text { Waktu angkut }(\mathrm{Wa}) & =3,170 \text { menit }\end{array}$


Waktu buang $\left(\mathrm{t}_{1}\right)$ $=0,7$ menit

Waktu kembali (Wk)

$=3,659$ menit

Waktu persiapan angkut $\left(\mathrm{t}_{2}\right)=0,871$ menit

$\mathrm{Cm}_{\mathrm{dt}}=\mathrm{Wm}+\mathrm{Wa}+\mathrm{Wk}+\mathrm{t}_{1}+\mathrm{t}_{2}$

$\mathrm{Cm}_{\mathrm{dt}}=8,4+3,170+3,659+0,7+0,871$

$\mathrm{Cm}_{\mathrm{dt}}=16,8$ menit

$\mathrm{P}_{\mathrm{dt}} \quad=\frac{60}{\mathrm{Cmdt}} \cdot \mathrm{C}_{\mathrm{b}} \cdot \mathrm{E}_{\mathrm{dt}}$

$\mathrm{P}_{\mathrm{dt}} \quad=\frac{60}{16,8} \cdot 20,6 \cdot 0,69$

$\mathrm{P}_{\mathrm{dt}} \quad=50,764 \mathrm{~m}^{3} / \mathrm{jam}$

$\underline{\text { Jumlah dump truck yang digunakan }}$

$\mathrm{M}=\frac{\mathrm{Pe}}{\mathrm{Pdt}}$

$\mathrm{M}=\frac{112,500}{50,764}=2,26 \approx 2$ buah

Match factor antara excavator dan dump truck

$\mathrm{MF}=\frac{\mathrm{N}_{\mathrm{dt}} \cdot \mathrm{s} \cdot \mathrm{Cm}_{\mathrm{e}}}{\mathrm{N}_{\mathrm{e}} \cdot \mathrm{Cm}_{\mathrm{dt}}}$

$\mathrm{MF}=\frac{2 \cdot 21 \cdot 0,4}{1.16,8}$

$\mathrm{MF}=1$

Sehingga efektivitas pengerukan sedimen maksimal jika setiap 1 buah excavator bekerja sama dengan 2 buah articulated dump truck. Alternatif waktu kerja excavator dan articulated dump truck di tahun 2017 dan 2018 tersaji pada Tabel 13 dan Tabel 14.

Tabel 13. Alternatif waktu kerja excavator dan dump truck tahun 2017

\begin{tabular}{cccc}
\hline Bulan & Shift & Waktu Kerja Excavator (jam) & Waktu Kerja DT (jam) \\
\hline \multirow{3}{*}{ Jun } & DS & 300 & 332,419 \\
& NS & 204,3 & 226,430 \\
Jul & DS & 300 & 332,419 \\
Ags & DS & 81,4 & 90,153 \\
Sep & & Tidak ada pengerukan & \\
& DS & 52,2 & 57,879 \\
Okt & DS & 310 & 343,499 \\
& NS & 253,8 & 281,202 \\
& DS & 310 & 343,499 \\
& NS & 253,8 & 281,197 \\
Nov & DS & 300 & 332,419 \\
& NS & 270 & 299,177 \\
Des & DS & 300 & 332,419 \\
& NS & 270 & 299,177 \\
& DS & 310 & 343,499
\end{tabular}




\begin{tabular}{cccc}
\hline Bulan & Shift & Waktu Kerja Excavator (jam) & Waktu Kerja DT (jam) \\
\hline \hline NS & 279 & 309,149 \\
& DS & 310 & 343,499 \\
& NS & 279 & 309,149
\end{tabular}

Pada tahun 2017, terdapat bulan dengan menggunakan 1 buah excavator yang bekerja sama dengan 2 buah articulated dump truck dan terdapat bulan dengan 2 buah excavator yang bekerja sama dengan 4 buah articulated dump truck.

Tabel 14. Alternatif waktu kerja excavator dan dump truck tahun 2018

\begin{tabular}{|c|c|c|c|}
\hline Bulan & Shift & Waktu Kerja Excavator (jam) & Waktu Kerja DT (jam) \\
\hline \multirow{4}{*}{ Jan } & DS & 310 & 343,499 \\
\hline & NS & 279 & 309,149 \\
\hline & DS & 310 & 343,499 \\
\hline & NS & 279 & 309,149 \\
\hline \multirow{4}{*}{ Feb } & DS & 280 & 310,257 \\
\hline & NS & 252 & 279,232 \\
\hline & DS & 280 & 310,257 \\
\hline & NS & 252 & 279,232 \\
\hline \multirow{4}{*}{ Mar } & DS & 310 & 343,499 \\
\hline & NS & 279 & 309,149 \\
\hline & DS & 310 & 343,499 \\
\hline & NS & 279 & 309,149 \\
\hline \multirow{4}{*}{ Apr } & DS & 300 & 332,419 \\
\hline & NS & 270 & 299,177 \\
\hline & DS & 300 & 332,419 \\
\hline & NS & 270 & 299,177 \\
\hline \multirow{4}{*}{ Mei } & DS & 310 & 343,499 \\
\hline & NS & 279 & 309,149 \\
\hline & DS & 310 & 343,499 \\
\hline & NS & 279 & 309,149 \\
\hline \multirow{4}{*}{ Jun } & DS & 300 & 332,419 \\
\hline & NS & 270 & 299,177 \\
\hline & DS & 300 & 332,419 \\
\hline & NS & 270 & 299,177 \\
\hline \multirow{4}{*}{ Jul } & DS & 310 & 343,499 \\
\hline & NS & 279 & 309,149 \\
\hline & DS & 310 & 343,499 \\
\hline & NS & 279 & 309,149 \\
\hline \multirow{4}{*}{ Ags } & DS & 310 & 343,499 \\
\hline & NS & 279 & 309,149 \\
\hline & DS & 310 & 343,499 \\
\hline & NS & 279 & 309,149 \\
\hline \multirow{4}{*}{ Sep } & DS & 300 & 332,419 \\
\hline & NS & 270 & 299,177 \\
\hline & DS & 300 & 332,419 \\
\hline & NS & 270 & 299,177 \\
\hline \multirow[t]{2}{*}{ Okt } & DS & 243,6 & 269,972 \\
\hline & DS & 300 & 332,419 \\
\hline \multirow{3}{*}{ Nov } & NS & 270 & 299,177 \\
\hline & DS & 300 & 332,419 \\
\hline & NS & 270 & 299,177 \\
\hline \multirow{2}{*}{ Des } & DS & 310 & 343,499 \\
\hline & NS & 279 & 309,149 \\
\hline
\end{tabular}




\begin{tabular}{cccc}
\hline Bulan & Shift & Waktu Kerja Excavator (jam) & Waktu Kerja DT (jam) \\
\hline & DS & 310 & 343,499 \\
& NS & 279 & 309,149 \\
\hline
\end{tabular}

Pada tahun 2018, dalam satu tahun digunakan 2 buah excavator yang bekerja sama dengan 4 buah articulated dump truck, kecuali pada bulan Oktober hanya menggunakan 1 buah excavator dan 2 buah articulated dump truck.

\section{Kesimpulan}

Berdasarkan studi yang sudah dilakukan didapatkan kesimpulan bahwa laju erosi dan laju sedimentasi yang tinggi terjadi pada tahun 2017 dan tahun 2018 di DTA Central Sediment Sump menjadikan volume sedimen yang terendapkan pada tampungan Central Sediment Sump pun tinggi dan membutuhkan pengerukan sedimen untuk menjaga fungsinya dalam mengendapkan sedimen. Pengerukan sedimen yang sudah dilakukan di tahun 2018 belum dapat mengeruk seluruh sedimen yang terendapkan di Central Sediment Sump sehingga dilakukan alternatif penggunaan excavator dan articulated dump truck untuk sebagai rekomendasi untuk pengerukan sedimen di Central Sediment Sump berdasarkan kondisi di tahun 2017 dan 2018.

\section{Daftar Pustaka}

[1] G. Subowo, "Penambangan Sistem Terbuka Ramah Lingkungan dan Upaya Reklamasi Pasca Tambang Untuk Memperbaiki Kualitas Sumberdaya Lahan dan Hayati Tanah," Jurnal Sumberdaya Lahan, vol. 5, no. 2, pp. 83-94, 2011

[2] I. M. Kamiana, Teknik Perhitungan Debit Rencana Bangunan Air. Yogyakarta: Graha Ilmu, 2010

[3] USDA, National Engineering Handbook. USA: USDA, 2004

[4] C. N. Widiyati, "Application of US-SCS Curve Number Method and GIS for Determining Suitable Land Cover of Small Watershed," IJG, vol. 2, no. 1, pp. 69-89, 2016

[5] M. M. Rantung, A. Binilang, M. E. Wulsan, and F. Halim, "Analisis Erosi dan Sedimentasi Lahan di Sub DAS Panasen Kabupaten Minahasa," Jurnal Sipil Statik, vol. 1, no. 5, pp. 309317, April 2013

[6] C. Asdak, Hidrologi dan Pengelolaan Daerah Aliran Sungai. Yogyakarta: Universitas Gajah Mada Press, 2004

[7] R. Asmaranto, R. A. A. Soemitro, and N. Anwar, "Changes of Soil Erodibility Due To Wetting and Drying Cycle Repetitions On The Residual Soil," International Journal of Academic Research, vol. 2, no. 5, pp. 149-152, 2010

[8] H. C. Hardiyatmo, Penanganan Tanah Longsor dan Erosi. Yogyakarta: Universitas Gajah Mada Press, 2006

[9] R. K. Linsley Jr., M. A. Kohler, and J. L. H. Paulhus, Hidrologi Untuk Insinyur. Jakarta: Erlangga, 1986

[10] S. F. Rostiyanti, Alat Berat Untuk Proyek Konstruksi. Jakarta: Rineka Cipta, 2008

[11] A. T. Tenriajeng, Pemindahan Tanah Mekanis. Jakarta: Gunadarma, 2003 